\title{
Alcoholism and Identity Change in Eugene O’Neill's Long Day's Journey into Night
}

\author{
Shno S. Alaaldin ${ }^{1}$,Hamid B. Abdulsalam² \\ ${ }^{1}$ MA Student at Department of English, Faculty of Humanities and Social Sciences, Koya University, Kurdistan Region, Iraq \\ ${ }^{2}$ Department of English Language, Faculty of Humanities and Social Sciences, Koya University, Kurdistan Region, Iraq
}

\begin{abstract}
Although much research has been written on the idea of substance abuse in the American theater, this paper presents a new perspective by discussing how the abuser can undergo an identity change. Drug and alcohol addiction is one of the salient themes of twentieth-century American theater. Playwrights like Eugene O'Neill depicted this social problem in their plays by drawing upon their own personal experience in substance abuse. The paper examines alcoholism and drug addiction in O'Neill's Long Day's Journey into Night. It shows how a ddicts experience identity change during the course of their addiction. The main argument, in this paper, is based on some sociological research on alcoholism and identity change proposed by Tammy L. Anderson. Identity transformation of the addicts may result from the existence of various personal and environmental factors, which correlate to personal and social identity respectively. These factors will be used in relation to the characters of the play to show how addicts and alcoholics pass through several stages to reach their final identity change. Those characters, by immersing themselves in substance intake, cease to belong to 'normals' and in their search for a new identity they liaise with 'deviants' where they find affinity. When the curtain is drawn, the addicted characters have already embarked on their journey which will end, both literally and figuratively, in haziness and fog, a strong indication of their loss of sense of existence and self-awareness.
\end{abstract}

KEY WORDS: Alcoholics, Anderson, Identity Change, Long Day's Journey into Night, O'Neill

\section{INTRODUCTION:}

In order to draw the line between this article and other academic works that discussed the idea of substance abuse in $\mathrm{O}^{\prime}$ Neill's Long Day's Journey into Night, the main points of those works will be presented in this section. To start with, Michael Hinde's article "The Pharmacology of Long Day's Journey into Night" (1990) could be the closest to our study in his approach to the play. In his article, Hinde draws upon the recent research findings in pharmacology on addiction which stipulate that if a patient is given morphine solely to

Koya University Journal of Humanities and Social Sciences (KUJHSS), Volume 4, Issue 1, 2021.

Received 19 May 2020; Accepted 18 Sep 2020,

Regular research paper: Published 30 Jun 2021

Corresponding author's e-mail: hamid.al-ani@koyauniversity.org

Copyright $\odot 2021$. Shno S. Alaaldin, Hamid B. Abdulsalam, this is an open access article distributed under the Creative

Commons Attribution License. control pain, it rarely leads to addiction. Hinde builds his argument on this finding to exonerate James Tyron, the father in the play, from the guilt of his wife's addiction. Thomas M. Campbell's doctoral dissertation "Alcoholism on the American Stage: De-Stigmatizing Socially Constructed Depictions of the Alcoholic through Performance" (2013) focuses on the dramaturgy of selected plays. O'Neill's Long Day's Journey into Night is one of the plays the dissertation tackles, in which the theme of alcohol abuse and the way the theatre and actors can initiate empathy and compassion towards alcoholics are discussed. The dissertation depicts how cultural stereotypes can perpetuate stigmas associated with alcohol intake/abuse. In her article "The function of drugs in Eugene O'Neill's "long day's journey into night" and Tennessee Williams' "a street car named desire" (2008), Nadine Esser studies the function of drinking or taking drugs for the characters of both plays. Esser relies on Sylvia Berke's book Familienproblem Alkohol to approach both plays from a psychological viewpoint. 
The present article analyzes the play to show how, in effect, substance abusers pass through a process of identity change. The analysis is mainly based on the findings of Tammy L. Anderson, a professor of sociology at the University of Delaware, and some other researchers. The study offers a new reading of O'Neill's play with regard to substance abuse and identity change. Before proceeding in our analysis, it is important to look at some sociological theories of substance abuse and identity transformation that the study relies on.

\section{SOCIOLOGICAL THEORIES OF SUBSTANCE ABUSE AND IDENTITY TRANSFORMATION}

Substance abuse has drawn the attention of many researchers that have studied this problem from a sociological viewpoint, trying to understand the underlying factors that lead to this devastating habit. Many studies have taken the effect of substance abuse on identity as their focus, and several of them have connected it to identity change like those of Tammy L. Anderson. In her articles on substance abuse and identity transformation, Anderson cites several other scholars whose works focus on identity transformation in both drug addicts and alcoholics. Generally, this abuse will lead to two types of transformation: alternations and conversions. Travisano (1970) and Bankston et al. (1981) define alternation as a slight change in identity while conversion is more radical and dramatic (quoted in Anderson 1993, p.134). The characters in O'Neill's Long Day's Journey into Night belong to the first type of identity transformation that is "alternation". The process is gradual and the more the characters drink the more detached from reality they become. In this type of transformation, the addict wishes to be ordinary, but being an addict to alcohol or drugs becomes a barrier for having an ordinary life.

By analyzing the etiology of this change, Anderson presents two main factors, personal (micro) and environmental (macro). Identity change process features three personal-level concepts (personal marginalization, ego identity discomfort, and loss of control in defining one's identity), and five environmental- level concepts (social marginalization and identification with a drug subcultural group, economic opportunity, educational opportunity, and popular culture) (Anderson 1998a, p.233). With the exception of "economic opportunity" and "popular culture", all the above-mentioned factors are present in the play. Ego identity discomfort entails "negative feelings" about addicts "present identity"; for example, feelings of "dissatisfaction, alienation, and depression, personal motivations to change, and the desire to fit in (Anderson 1994, p.161). Anderson and Mott maintain that personal marginalization includes "the tragic events that happen in one's life such as: the death of someone significant, and frequent geographic moves of the family" (1998b, p.4). In her 1999 research, Anderson adds another macro factor to identity change, "a social climate conductive to drug use" (p.2). This factor can drive people to drink or take drugs to fit in with the world in which they live. A drug-oriented culture, like the one in the play, would eventually be divided into two groups: "normals" and "deviants", or "We" and "They" (Anderson 1994, pp.159-161). Anderson reaffirms that "marginalized individuals" search to be part of a group of people, to "belong" to a group and alcohol or drug helps them to fit in a group and facilitate their relation to have an identity (1999, p.34). As such, the intoxicated characters in O'Neill's Long Day's Journey into Night go through these stages that Anderson explored until in the end of the play they remain lonely, desperate, and unable to return to their normal state.

\section{EUGENE O'NEILL'S LONG DAY'S JOURNEY INTO NIGHT}

O'Neill completed Long Day's Journey into Night (henceforth LDJN) in 1940 and was posthumously published in 1956 by his wife. O'Neill is certainly regarded one of the few playwrights who had the courage to depict alcoholics in his plays during the first half of the twentieth century. Abbotson states that not until the 1950s, the issue of substance abuse remained filled with pitfalls and the public's general tendency was to shun similar topics on stage for fear of promoting or encouraging the taking of drugs or alcohol (2003, p.233). Harold Bloom considers the play to be "the best play in our more than two centuries as a nation" (2009, p.1). O'Neill believed in the power of the word to bring about a change in the American society by shedding light on serious social issues of alcoholism and drug addiction. Being a "domestic tragedian" (Bogard 1988, p.431-432), O'Neill, in his autobiographical play, draws on his reallife experience of his alcoholic family to delineate the devastating results of substance abuse. The play, without impairing its artistic value, offers a realistic account of the suffering and pain the characters endure because of their addiction. Thus, it is not surprising to find that the play can yield new meaning in view of these recent sociological theories.

The play's title entails a dynamic or a process of change from day into night, light into dark, and affirmation into negation. It is interesting to note how the title may be an indicative of this identity change that the characters are doomed to face due to their addiction. The characters are similar to the members of O'Neill's family. The play includes four main characters: James Tyrone, the father who was a well-known actor, Mary, the mother, is the representation of his mother Ellen Quinlan O'Neill; Jamie, the elder son, and Edmund, the 
younger son who stands for O'Neill. The three men in the play are alcoholics and their mother, Mary, is a morphine addict. All the characters are victims of excessive Alcohol intake and thus undergo identity change due to several personal and environmental factors. The first main factor in the play is that actors and events are presented against a broad background of a culture of substance abuse; thus, creating a social milieu conductive to lavish intake. The stage is full of alcoholics and the parents are legitimizing this excessive intake for their children under the plea that drinking 'in moderation' is acceptable and it is 'a good appetizer.' The second factor is the constant geographical moves of the family; the Tyrones never had a house but kept moving from one filthy hotel to another. Building on these two factors, the play provides strong social underpinnings for the doom awaiting the family. Having no strong social ties can basically impede any healthy identity growth. Gregory Stone maintains that identities are 'situated action' (quoted in Katovich 1987, p. 188) which means that an individual defines one's identity in relation to their social context. The Tyrones fail to develop long lasting social relations because of frequent changing of their living place, a fact which has a detrimental role shaping their current identities.

In the play, $\mathrm{O}^{\prime}$ Neill depicts three generations that cannot escape alcoholism and its curse, which is an epitome of the whole of America. Campbell maintains that "the American society is a drug-oriented society, an addiction society, a society preoccupied with drugs, alcohol, their consumption and social control. Two-faced in its attitudes, American society encourages alcohol consumption, but does not want alcoholics (2013, p.1). The alcoholics in the play feels alienated and no longer able to socialize with people because their identities as 'normals' have dramatically been strained and altered. These three generations are the older generation as represented by Mary's father and Cathleen's uncle; the present generation which is represented by Tyrone and Mary; while Jamie, Edmund, and Cathleen stand for the future one. Cathleen, the servant, while serving Edmund with a glass of whisky, speaks of how alcohol "killed an uncle of mine in the old country" (LDJN, p. 45), and upon seeing the glass of whisky that Edmund had, Mary fumes with anger and blames Tyrone for his son's addiction: “Do you want to kill him? Don't you remember my father? He wouldn't stop after he was stricken...He thought, like you, that whiskey is a good tonic!" (LDJN, p. 58). Tyrone and Mary should have been the center that holds the family members together, but because of the father's alcoholism and the mother's addiction to morphine, the social atmosphere of the family is lacking in love, affection, and care. The two sons cannot help but follow their parents' steps to the bars, where the subculture of substance intake creates an alternate identity with which they easily identify. In the bars, the community of 'deviants' alleviates the sense of loss and alienation the two brothers feel because, as socially 'marginalized individuals', they seek refuge in places where this sense of loss can be substituted by a temporary feeling of existence, creating thus a kind of alternate identity. However, this alternate identity can only aggravate the sense of loss and purposelessness. The bars, whores, and drunkards the two sons linger on cannot substitute the reality of the outside world, and while they provide a temporary relief, their effect is that of alcohol itself. Alcohol intoxicates but cannot create a sustainable and lasting alternative to the real world.

The culture of substance abuse depicted in the play is strong enough to entangle all members in its snares. Its effect is that of dominos, when one falls all others follow. An alcoholic family will create an atmosphere in which its members have ego identity discomfort that would consequently create a disintegrated individual. O'Neill shows how drinking became a dominant culture by referring to the ways drinking is justified and beautified. Tyrone speaking to Edmond says "I've always found that good whiskey, taken in moderation as an appetizer, is the best of tonics" (LDJN, p. 56), which is something he repeats throughout the play; Mary, repeating the same idea, declares: "One small drink won't hurt Edmund. It might be good for him, if it gives him an appetite" (LDJN, p.58-59); Cathleen, also says: "a drop now and then is no harm when you're in low spirits, or have a bad cold" (LDJN, p.45); Edmund, however, quotes lines from Baudelaire: "Be always drunken. Nothing else matters: that is the only question. ... Drunken with what? With wine, with poetry, or with virtue, as you will but be drunken" (LDJN, p.114). The alcoholic father finds that alcohol is the best cure for his sons' illnesses when they were children. He used to give them whiskey to relieve their pains, as Mary talks about Jamie's childhood:

You brought him up to be a boozer. Since he first opened his eyes, he's seen you drinking. Always a bottle on the bureau in the cheap hotel rooms! And if he had a nightmare when he was little, or a stomach-ache, your remedy was to give him a teaspoonful of whiskey to quiet him (LDJN p.9596).

The dominant identity now is that shaped and defined by alcohol intake. Alcohol is now an integrated aspect of their lives. It is a medication, a leisure, a pass time, the best tonic when one of the characters is disheartened, and most importantly a definer of the characters' existence and belonging.

One of the first indications that the family is living a life of deviants is their staying in their secluded summer house far away from ordinary people. Alcohol and drug addiction alienates them from the rest of the society. 
However, the fact that a thick fog wall surrounds them indicates that they will no more have any contact with the outside world. The characters go outside only to meet friends in the bars or clubs, or to find a place where they can be alone. Edmund, for example, goes to the sea where he sees a beautiful world that he cannot cope with or be part of, which is the world of nature. His inability to become part of nature is because he is an alcoholic, meaning that he lacks the purity which is essential to become part of it:

When I was swimming far out, or lying alone on a beach, I have had the same experience. Became the sun, the hot sand, green seaweed anchored to a rock, swaying in the tide like a saint's vision of beatitude. Like the veil of things as they seem drawn back by an unseen hand. ...For a second there is meaning! Then the hand lets the veil fall and you are alone, lost in the fog again, and you stumble on toward nowhere, for no good reason!... It was a great mistake, my being born a man, I would have been much more successful as a seagull or a fish. As it is, I will always be a stranger who never feels at home, who does not really want and is not really wanted, who can never belong, who must always be a little in love with death! (LDJN, p.134-135)

The indirect comparison that Edmund holds between himself and Prufrock is striking. Eliot's Prufrock is a "patient etherized" and suffers from an identity crisis as a modern man lost in the ramifications of modern life. $\mathrm{He}$ is etherized and intoxicated by the overwhelming experience of being alive. Prufrock believes that he should have been "a pair of ragged claws/ scuttling across the floors of silent seas", where he can forever hide from people due to his inability to face life. The ghost of death, in the image of "the eternal footman", is hovering on the whole poem. Prufrock's inability to socialize relegates him to the margins of society where he views himself as a worm "wriggling on a wall", a cheap commodity of modern industry. His suffering is a direct outcome of his lack of any well-defined personal identity. Consequently, he is conscious of his social inadequacies and believes that he should have never been born a man. He may fit into the roles of other creatures but not of a 'social animal', to borrow the sociological definition of the human being. Similarly, Edmund feels like an outsider because of alcohol-caused limitations. Edmund's search for meaning is a search for a definition of his existence, a purpose for his life, and an identification of his being. In a world of intoxication, his identity as a man only flickers, leaving him groping in darkness for meaning. He is both socially and selfmarginalized, a stranger who lacks any sense of belonging. Edward never feels 'at home', an expression that is repeated several times by other characters as well.
In this respect, Kurt Eisen affirms that "For the Tyrones, to feel "at home" means to have an identity built on a strong sense of connection to a place and to a stable family architecture; paradoxically, their sense of family is built on a general mistrust of home as a concept" (2009, p. 89). Tyron's acting career is to be blamed for the family's lack of permanent home, the thing that leads to Mary's chronic suffering.

For a nuclear family like the Tyrones, moving from one place to another defines their identity and existence. The "dirty rooms of filthy hotels" (LDJN, p.113) Mary repeatedly complains, as opposed to a real home, embodies the identity problem the whole family suffers from. Identity shifts as the social context keeps shifting. The social identity of the family members is as shallow and inconsistent as that of the hotel rooms. Hotel rooms are not individualistic; they are generic, in the sense that they belong to many different people at many different times. However, personal identity is a person's fingerprint because it distinguishes the person from other people. Symbolically, home shapes ones identity in the sense that it connects the person to a fixed and more stable social milieu. John Lock defined personal identity as an identity of consciousness through duration in time. He highlights the role of memory in connecting a person's identity to their past thoughts and actions (quoted in Ian Watt 1957, p. 21). Having a shattered memory of constant moving from one hotel to another deflates ones sense of existence and belonging to a specific place. This sense of belonging may be shown in ones connections and friends. There is scarcely any reference to friends in the play, and the only friends mentioned are those of barrooms. Even when the family finally settles down in its own house in a small town, Mary says the following:

I've never felt it was my home. ...Your father would never spend the money to make it right. It's just as well we haven't any friends here. I'd be ashamed to have them step in the door. But he's never wanted family friends. He hates calling on people, or receiving them. All he likes is to hobnob with men at the Club or in a barroom. Jamie and you are the same way, but you're not to blame. (LDJN, p.38)

Having no sense of belonging to any social community other than that of barrooms intensifies their feeling of being deviants, and thus, relegates them to the margins of society. Mary reiterates on the fact that Tyron and the sons do not have a healthy sense of a home by saying, "[Tyron] doesn't understand a home. He doesn't feel at home in $\mathrm{it}^{\text {", }}$ and "[The boys] have too good an excuse to remain in the barrooms where they feel at home" (LDJN, p.53 \& p.85). Thus, for the family members to feel 'at home', they change their home into a bar-like place by their heavy consumption of alcohol 
and, in Mary's case, by doping. Mary herself has "never felt at home in the theater. Even though Mr. Tyrone has made me go with him on all his tours, I've had little to do with the people in his company or with anyone on the stage. I've never felt at home with them. Their life is not my life. It has always stood between me and -" (LDJN, p.87-88), leaving the sentence unfinished. One wonders whether the theater deprived her of something. Mary's inability to come into terms with her husband's profession, which reflects his life and identity, has created the schism that deep crack in the family relations within itself and with the outside world. She certainly fails in being the center of gravity to hold all the family members together to give her home the maternal affection mostly needed by the boys. In response to this failure, Jamie comments "Christ, I'd never dreamed before that any women but whores took dope!" (LDJN, p.143). The emotional restlessness and vacuum that the sons have because of their mother's addiction appears in Jamie's behavior and personality. Jamie goes to the bars to spend his time with whores in search for love and "feminine companionship", as he admits: "Sure thing. Where else could I find suitable feminine companionship? And love. Don't forget love. What is a man without a good woman's love? A God-damned hollow shell" (LDJN, p.139). So, Mary fails to be a decent mother for her sons. For this reason, Jamie states, "All I wanted was a little heart-to-heart talk concerning the infinite sorrow of life" (LDJN, p.140). As a result, he goes to the bar to talk about sorrows of life with a whore instead of a mother.

This sense of having no real identity like normal people is echoed several times in the play. One remarkable way is when $\mathrm{O}^{\prime}$ Neill associates it with the fog. The fog and its related foghorn, which is a loud sound used to warn ships of foggy conditions, constitute a good part of the play and is referred to by several actors. Critics and scholars have carried out sufficient analysis of the role of those two elements. However, no relation has been drawn between these two to alcohol intake. The fog has been interpreted as the characters refuge from reality and the foghorn as the call from the outside world that keeps intruding. While this is a valid interpretation in view of the events of the play, it misses one essential meaning of these two elements. While fog represents a refuge, it is also the refuge induced and created by intoxication. It is the hazy world where the alcoholic characters find belonging to and identity with themselves and the world of barrooms. It is their alternate identity. However, once this intoxication diminishes, as represented by the foghorn, the sense of identity and belonging soon disappears leaving the characters in the world of reality, utterly alone and broken. Thus, Mary, speaking to Cathleen, states "It wasn't the fog I minded, Cathleen, I really love fog...It hides you from the world and the world from you. You feel that everything has changed, and nothing is what it seemed to be. No one can find or touch you any more", and she continues, saying, "It's the foghorn I hate. It won't let you alone. It keeps reminding you, and warning you, and calling you back" (LDJN, p.84-85). Edmund, similarly, shows his love to the fog: "I loved the fog. It was what I needed" (LDJN, p.112), and about the foghorn, he says, "That damned foghorn kept me awake, too" (LDJN, p.48). The family's attempts to find a new identity have all been thwarted by the intrusive reality of the outside world. Alcohol has stripped them of their social identity and replaced it with one that is fragile and elusive.

In addition, this identity problem is shown in the language spoken by the characters. In this respect, Bruce J. Mann maintains that by tracing some linguistic patterns of the characters like the repetition of certain words, for example "gloom/gloomy," "lonely," "lie," "alone," "fog," "lost," "see," "poison," "peace/peaceful," "happy," "home," "night," "forget," "understand," "life," beside other linguistic patterns, one can see that the characters "do not possess a unique, distinguishable voice." (2009, p. 12). Language and identity have reciprocal effect and one shapes the other. Having no distinctive voice necessarily means that each character does not have a distinct identity of his/her own. This lack of a clear distinguishable linguistic identity can be attributed to the characters' lack of any real interaction with people. Their life experience is confined to the limited world of home and barrooms. This linguistic pattern is especially true about James Tyron. As an actor in his youth, an important aspect of his personality is revealed by $\mathrm{O}^{\prime} \mathrm{Neill}:$ " the actor shows in all his unconscious habits of speech, movement and gesture through him" (LDJN, p.11); however, Mary provides a deeper insight on this point by stating "You don't know how to act in a home!" (LDJN, p.58). Acting entails a sense of empathy of the role; thus, it seems that the only identity Tyrone can show is that of acting, and the most important role of a father and husband is the one he fails at disgracefully. He lacks any genuine identity of his own and the only role he perfects is that of an "entertainer [of] friends in bar-rooms!" (LDJN, p.58) as Mary explains. Tyron is even caught by his family members repeating certain phrases and words, which is an indication of his stereotypical personality. An example of this is when he tells Jamie "Ingratitude, the vilest weed that grows", for which Jamie replies "I could see that line coming! God, how many thousand times !" (LDJN, p.28).

Tyron used to enjoy a great reputation as an actor but that did not last for a long time. Tyrone's ego identity discomfort, which is the feeling of dissatisfaction with one's current identity and social status, is due to his 
depressed life that directed him to alcoholism. Being an alcoholic was not his will power and he was not the one who shaped his personality, but "life has made him like that, and he can't help it" (LDJN, p.53). What created his personality is his bitter life and poverty in his childhood. Mary sheds light on this fact while speaking to Jamie: "he's worked hard all his life. He made his way up from ignorance and poverty to the top of his profession!" (LDJN, p.52). In fact, this ego identity discomfort manifests itself not in Tyron alone but in Mary and Jamie as well. Jamie, on one hand, is forced by his father to be an actor, "I never wanted to be an actor. You forced me on the stage", which is a profession he does not really like and as a result, he loses control over defining his own identity. Jamie fails to become the person Tyrone is expecting him to be and he will be the disgrace of the family, as Mary states: "Who would have thought Jamie would grow up to disgrace us. You remember, James...we received such glowing reports. Everyone liked him" (LDJN, p.95) when he was at school. Jamie had a prosperous educational opportunity which he lost when he started drinking. He was expelled from school and thus he suffered from both social marginalization and ego identity discomfort. Therefore, his identity changes from being a "brilliant student" who would have a "wonderful future" (LDJN, p.95) to being "a drunken loafer" (LDJN, p.96). Through Jamie's character O'Neill makes it clear how alcohol has a significant effect on human life. It takes away all the hopes of success and prosperity and leaves man in a degraded, pitiable condition. On the other hand, Mary's ego identity discomfort is evident in the disillusionment with her present condition, which she expresses in her dialogue with Cathleen. She considers, although indirectly, that her marriage to James Tyrone as the starting point of her miseries that directs her to morphine addiction. Her marriage prevents her from making the dream of becoming a pianist or a nun a reality. She explains

[My father] would have sent me to Europe to study after I graduated from the Convent. I might have gone-if I hadn't fallen in love with Mr. Tyrone. Or I might have become a nun. I had two dreams. To be a nun, that was the more beautiful one. To become a concert pianist, that was the other (LDJN, p.89).

In this way, she experiences the ego identity discomfort and the loss of control in defining her identity that would make her feel alienated, depressed and dissatisfied. The death of her son, Eugene, is a micro factor that contributed to pushing her towards addiction. As a consolation to Eugene's death, she became pregnant. After giving birth to Edmund, she became sick, and was given morphine by a doctor to sooth her pain but she became an addict to it.
In order to show the divergence of the family from the normal life and the change of its identity as a family, O'Neill establishes a comparison between the first appearance of the family and that of the following acts. The familial love and warmth that is shown in the first act will no more exist. In the first act in which everything is normal, the family is presented on stage as having a wonderful time together and the audience can feel their love and closeness to one another: "As the curtain rises, the family have just finished breakfast. Mary Tyrone and her husband enter together" (LDJN, p.10). This togetherness that is seen in the first act will not be seen in acts II. O'Neill tells us:

The family are returning from lunch as the curtain rises. Mary is the first to enter from the back parlour. Her husband follows. He is not with her as he was in the similar entrance after breakfast at the opening of Act One. He avoids touching her or looking at her. There is condemnation in his face, mingled now with the beginning of an old weary, helpless resignation. Jamie and Edmund follow their father (LDJN, p.61).

In the last act, the three men gather around the table at about midnight to have whisky while the whole house seems to be sinking in darkness:

The lamp in the front hall has been turned out, so that now no light shines through the front parlor. In the living room only the reading lamp on the table is lighted. Outside the windows, the wall of fog appears denser than ever. (LDJN, p.108).

Darkness and a denser fog enshroud the family now, a strong symbol of the permanent identity change that happened to them as a family and as individuals. The closing scene is probably the most powerful in showing how their closeness is constantly disrupted by alcohol until the connection between the family members and their connection to the outside world is fully ruined:

Tyrone: Oh, we're fools to pay any attention. It's the damned poison. But I've never known her [Mary] to drown herself in it as deep as this. (Gruffly.) Pass me that bottle, Jamie.... (Jamie pushes the bottle toward him.... Jamie pours his and passes the bottle to Edmund, who, in turn, pours one. Tyrone lifts his glass and his sons follow suit mechanically, but before they can drink Mary speaks and they slowly lower their drinks to the table, forgetting them). (LDJN, p.154-155)

Mary then, laden with morphine, starts speaking about her past dream to be a nun until the moment she met Tyrone and forgot about that dream:

Mary (staring dreamily before her... The shyly eager, trusting smile is on her lips as she talks aloud to herself ): I had a talk with Mother Elizabeth. ... I told her I wanted to be a nun. I explained how sure I was of my vocation, that I had prayed to the Blessed Virgin to make me sure, and to find me worthy.... But Mother Elizabeth told me I must be more sure 
than that, even, that I must prove it wasn't simply my imagination. She said, if I was so sure, then I wouldn't mind putting myself to a test by going home after I graduated, and living as other girls lived, going out to parties and dances and enjoying myself; and then if after a year or two I still felt sure, I could come back to see her and we would talk it over again. ... (She pauses and a look of growing uneasiness comes over her face. She passes a hand over her forehead as if brushing cobwebs from her brainvaguely.) That was in the winter of senior year. Then in the spring something happened to me. Yes, I remember. I fell in love with James Tyrone and was so happy for a time. (She stares before her in a sad dream. Tyrone stirs in his chair. Edmund and Jamie remain motionless.) CURTAIN (LDJN, p.155156).

Mary has gone to a point beyond return in her addiction to morphine. Therefore, she is now beyond redemption when it comes to restoring her sense of identity. She is forever caught in her past sense of identity as a would-be nun. It seems as if any reconciliation attempt with her present reality and with life as a whole is doomed to fail. This yearning for an unreturnable past pushes her further into addiction, a fact that leaves its strong impact on constructing family identity. For the three men, the glasses of whisky will always be there hindering any attempt to be normal. The way Tyrone pushes the bottle to his elder brother, who I his turn passes it to his younger brother is strongly correlated to the way they mechanically follow their father's steps. It is the inevitable dominos again falling one after the other. The sons have lost their sense of existence and have turned into robots imitating their father. All the members of the family are crippled and they cannot take any step toward having a better life away from intoxication. They represent the alcoholics who lost their life and their "true self" as Mary says: " None of us can help the things life has done to us. They're done before you realize it, and once they're done, they make you do other things until at last everything comes between you and what you'd like to be, and you've lost your true self forever" (p.53) In the end, Mary's words echo forever.

\section{CONCLUSIONS}

This paper provides a new interpretation of O'Neill's Long Day's Journey into Night by making use of some sociological theories on substance abuse and identity change. These sociological theories maintain that identity change only happen when a number of factors, personal and environmental, are at work. The paper shows with evidence from the play how this identity change is happening to the relevant characters. His focus as appears in the analysis of the play parallels
Anderson's notions about alcoholics in that each character in the play became an addict because of some micro and macro factors. Apart from the social environment of America that is conductive to substance use, the family itself has an environment in which alcoholics or drug addicts can easily be created. Moreover, the ego identity discomfort of each character and their feelings of dissatisfaction make them resort to alcohol consumption or drug intake. Therefore, their identity transforms gradually until at the end of the play they become unredeemable. This identity transformation deviate them from the normal part of the society. Thus, they will remain suffering endlessly for they cannot regain their true identity and be accepted as a normal person in their society. O'Neill intends to show how drug or alcohol intake can deviate and marginalize people from the normals. In fact, he clarifies this idea by presenting changes in the characters' lives. All the changes that happen to the characters are due to alcohol and drug consumption, the thing that will change their personality completely and lead them into darkness, despair, and loneliness. Overall, Tyrone family is transformed their life to darkness, their love to hatred, their hope to disappointment, their dreams to emptiness, and their strength to weakness. Therefore, they are preys in the hands of the long-established culture of alcoholism and drug addiction that is imposed on them the moment they are born.

\section{REFERENCES}

Abbotson, S.C.W., (2003). "Thematic Guide to Modern Drama". [ebook] West port: Greenwood. https://books.google.iq [Accessed 22September 2018]

Abdulsalm,H. B. (2020) "Demystifying the Other: A Study in Owen's "Strange Meeting" and Hardy's 'The Man He Killed'", Koya University Journal of Humanities and Social Sciences, 3(1), p p. 63-68. doi:https:// doi.org/10.14500/kujhss.v3n1y2020.pp63-68

Anderson, T. L., (1993). "Types of IdentityTransformation in DrugUsing and Recovery Careers". Sociological Focus, [e-journal] 26 (2), pp.133-145. www.jstor.org/stable/20831653 [Accessed 27 July 2019].

Anderson, T. L., (1994). “Drug Abuse and Identity: Linking Micro and Macro Factors". The Sociological Quarterly, [e-journal] 35 (1), pp. 159-174. www.jstor.org/stable/4121249 [Accessed 27 July 2019].

Anderson, T. L., (1998a). "A cultural-Identity Theory of Drug Abuse". Sociology of Crime, Law, and Deviance, [e-journal] (1), p p. 233 262.

https:// www.researchgate.net/publication/255604522_A_Cultu ral Identity Theory of Drug Abuse [Accessed 27 July 2019].

Anderson, T. L., (1998b). “Drug Identity Change Processes, Race, And Gender. I. Explanations of Drug Misuse and A New IdentityBased Model". Ethnicity and Substance Use, [e-journal] pp.1-10 https://www.researchgate.net/publication/13528019 Drug_Ide ntity Change Processes Race and Gender I Explanations of Drug_Misuse and a New Identity Based Model [Accessed 27 July 2019] 
Anderson, T. L., (1999). “Drug Identity Change Processes, Race, and Gender. III. Macrolevel Opportunity Concepts". [e-journal] USA: University of Illinois. pp.1-89 https:// www.researchgate.net/publication/13419599_Drug_Ide ntity Change Processes Race and Gender III Macrolevel Opp ortunity Concepts [Accessed 27-July 2019]

Bloom, H. ed., (2009). “Bloom's Modern Critical Interpretations: Eugene O'Neill's Long Day's Journey into Night". New York: Infobase publishing.

Bogard, T., (1988). "Contour in Time: The Plays of Eugene O'Neill”. [ebook] New York: Oxford University Press. https:// books.google.iq [Accessed 13 January 2020]

Campbell, T. M., (2013). "Alcoholism on The American Stage: Destigmatizing Socially Constructed Depictions of The Alcoholic Through Performance". Southern Illinois University Carbondale. <https://opensiuc.lib.siu.edu>viewcontent> [Accessed 12 September 2018].

Eisen, Kurt, (2009). “The Spare Room: Long Day's Journey into Night. In: H. Bloom, Ed., Bloom's Modern Critical Interpretations: Eugene O'Neill's Long Day's Journey into Night". New York: Infobase publishing. pp. 85-112.

Esser, N., (2008), “The Function of Drugs in Eugene O'Neill's "Long Day's Journey into Night" and Tennessee Williams' "A Street Car Named Desire". [e-book] s.l.: GRIN Publishing. https:// www.amazon.com/function-O'Neills-TennesseeWilliams-Streetcar/dp/3638906116 [Accessed 26 May 2019]

Hinden, M., (1990). “The Pharmacology of Long Day's Journey into Night". Penn State University Press, [e-journal] 14(1/2), p p. 47 51. https://www.jstor.org/stable/29784382 [Accessed 11 December 2019]

Katovich, M. A., (1987). "Identity, Time, and Situated Activity: An Interactions Analysis of Dyadic Transactions". Wiley, [e-journal] 10 (2), pp.187-208. https://www.jstor.org/stable/10.1525/si.1987.10.2.187 [Accessed 23 August 2020]

Mann, Bruce J. (2009). “O'Neill's “Presence” In Long Day's Journey into Night. In: H. Bloom, Ed., Bloom's Modern Critical Interpretations: Eugene O'Neill's Long Day's Journey into Night". New York: Infobase publishing. pp. 7-18.

O'Neill, E., (1966). “Long Day's Journey into Night”. London: Jonathan Cape.

Watt, I., (1957). “The Rise of The Novel”. London: Random House. 